\begin{tabular}{|c|l|}
\hline Title & Western A rctic primary productivity regulated by shelf-break warm eddies \\
\hline Author(s) & Watanabe, Eiji; Kishi, Michio J.; Ishida, A kio; A ita, Maki Noguchi \\
\hline Citation & $\begin{array}{l}\text { Journal of oceanography, 68(5), 703-718 } \\
\text { https://doi.org/10.1007/310872-012-0128-6 }\end{array}$ \\
\hline Issue Date & 2012-10 \\
\hline Doc URL & http://hdl.handle.net/2115/53444 \\
\hline Rights & The original publication is avail lable at www.springerlink.com \\
\hline Type & article (author version) \\
\hline File Information & Journal of Oceanography.pdf \\
\hline
\end{tabular}

Instructions for use 


\section{Western Arctic Primary Productivity Regulated By Shelf-break Warm Eddies}

Eiji Watanabe ${ }^{1}$

Michio J. Kishi ${ }^{1,2}$

Akio Ishida ${ }^{1,3}$

Maki Noguchi Aita ${ }^{1,2}$ 
E. Watanabe: Japan Agency for Marine-Earth Science and Technology, 3173-25, Showa-machi, Kanazawa-ku, Yokohama, Kanagawa, 236-0001, JAPAN (Tel: +81-45-778-5675, email: ejnabe@jamstec.go.jp)

${ }^{1}$ Japan Agency for Marine-Earth Science

and Technology, 3173-25, Showa-machi,

Kanazawa-ku, Yokohama, Kanagawa,

236-0001, JAPAN

${ }^{2}$ School of Fisheries Sciences, Hokkaido

University, N13 W8, Sapporo, Hokkaido,

060-0813, JAPAN

${ }^{3}$ Department of Social Environment, Fuji

Tokoha University, 325 Ohbuchi, Fuji,

Shizuoka, 417-0801, JAPAN 
WATANABE: WESTERN ARCTIC PRIMARY PRODUCTIVITY REGULATED BY EDDIES X - 3

\section{Abstract}

${ }_{4} \quad$ The response of phytoplankton to the Beaufort shelf-break eddies in the

5 western Arctic Ocean is examined using the eddy-resolving coupled sea ice-

${ }_{6}$ ocean model including a lower-trophic marine ecosystem formulation. The

7 regional model driven by the reanalysis 2003 atmospheric forcing from March

s to November captures the major spatial and temporal features of phytoplank-

9 ton bloom following summertime sea ice retreat in the shallow Chukchi shelf

10 and Barrow Canyon. The shelf-break warm eddies spawned north of the Bar-

11 row Canyon initially transport the Chukchi shelf water with high primary

${ }_{12}$ productivity toward the Canada Basin interior. In the eddy-developing pe-

${ }_{13}$ riod, the anti-cyclonic rotational flow along the outer edge of each eddy mov-

${ }_{14}$ ing offshore occasionally traps the shelf water. The primary production in-

${ }_{15}$ side the warm eddies is maintained by internal dynamics in the eddy-maturity

${ }_{16}$ period. In particular, the surface central area of an anti-cyclonic eddy ac-

${ }_{17}$ quires adequate light, nutrient, and warm environment for photosynthetic

${ }_{18}$ activity partly attributing to turbulent mixing with underlying nutrient-rich

19 water. The simulated biogeochemical properties with the dominance of small-

${ }_{20}$ size phytoplankton inside the warm eddies are consistent with the observa-

${ }_{21}$ tional findings in the western Arctic Ocean. It is also suggested that the light

${ }_{22}$ limitation before autumn sea ice freezing shuts down the primary produc-

${ }_{23}$ tion in the shelf-break eddies in spite of nutrient recovery. These results in-

${ }_{24}$ dicate that the time lag between the phytoplankton bloom in the shelf re-

${ }_{25}$ gion following the summertime sea ice retreat and the eddy generation along 
X - 4 WATANABE: WESTERN ARCTIC PRIMARY PRODUCTIVITY REGULATED BY EDDIES

${ }_{26}$ the Beaufort shelf break is an important index to determine biological regimes

27 in the Canada Basin.

${ }_{28} \quad$ Keyword :

29 phytoplankton bloom

30 eddy dynamics

$31 \quad$ shelf-basin exchange

32 Pacific-origin water

33 a lower-trophic marine ecosystem model 


\section{Introduction}

The influence of abrupt sea ice retreat on the Arctic marine ecosystem is a crucial topic

35 in academic, commercial, and social communities [Arrigo et al., 2008; Pabi et al., 2008].

${ }_{36}$ Recent satellite analysis indicated that high primary production region shifts northward

${ }_{37}$ from the Bering Sea to the Chukchi Sea following sea ice reduction [Grebmeier et al.,

38 2010]. While the systematic field campaign conducted in the Western Arctic Shelf-Basin

39 Interaction (SBI) project has produced major important findings in the 2000s [Grebmeier

40 and Harvey, 2005; Grebmeier et al., 2009], an impact of ocean dynamics on polar bi-

${ }_{41}$ ological cycles still has a lot of uncertainties. The Pacific-origin water inflowing from

${ }_{42}$ the Bering Strait is a predominant source of not only heat and fresh water, but also

${ }_{43}$ nitrate, silicate, dissolved- and particulate organic materials in the Arctic Ocean. The

${ }_{44}$ nutrient-rich Pacific water undergoes physical and biogeochemical modifications through

${ }_{45}$ seasonal primary production and interactions with organic-rich bottom sediments in the

${ }_{46}$ Chukchi shelf [Weingartner et al., 2005]. The buoyant Pacific summer water flows along

${ }_{47}$ the Alaskan northwestern coast as a surface-intensified current, and its significant part is

${ }_{48}$ eventually transported into the Canada Basin by shelf-break eddies during late summer

49 and early autumn [Pickart, 2004; Watanabe and Hasumi, 2009].

50 In the northern Gulf of Alaska, anti-cyclonic eddies propagating along a continental ${ }_{51}$ slope were frequently detected by satellite remote sensing [Okkonen et al., 2003]. The ${ }_{52}$ eddy-like features of high chlorophyll- $a$ (CHL) concentration implied that mesoscale eddies 53 were carrying phytoplankton and nutrient from the outer shelf toward the deep basin. In ${ }_{54}$ Ueno et al. [2010], the role of the Alaskan Stream eddies in the CHL distribution in the 


\section{X - 6 WATANABE: WESTERN ARCTIC PRIMARY PRODUCTIVITY REGULATED BY EDDIES}

${ }_{55}$ central subarctic North Pacific was categorized into three types: 1) the lateral transport of

${ }_{56}$ shelf-origin nutrient and biological organism via advection of eddy body and/or rotational

${ }_{57}$ circulation around of each eddy, 2) nutricline shallowing accompanied by eddy decay, and

$\left.{ }_{58} 3\right)$ Ekman upwelling induced by eddy-wind interaction. The latter two processes work

${ }_{59}$ on upward nutrient flux. Thus biological activities could be closely related to mesoscale

${ }_{60}$ eddies. In the western Arctic, eddy contribution to phytoplankton activities has not been

${ }_{61}$ fully evaluated yet. It is reported that the surface and halocline layers above $300 \mathrm{~m}$ depth

${ }_{62}$ in the Canada Basin are full of a number of anti-cyclonic eddies [Manley and Hunkins,

63 1985]. A major part of anti-cyclonic cold-core eddies are considered to be generated

${ }_{64}$ from a bottom-intensified current along the northern edge of Chukchi shelf via baroclinic

${ }_{65}$ instability in early spring [Spall et al., 2008]. Mathis et al. [2007] and Kadko et al. [2008]

${ }_{66}$ suggested that a cold eddy observed on the Chukchi Sea continental slope played a crucial

${ }_{67}$ role in the transport of carbon, oxygen, and nutrient associated with the Pacific winter

${ }_{68}$ water. However, the cold-eddy intrusion into the halocline layer of Canada Basin hardly

${ }_{69}$ enforces primary production in the surface euphotic zone at once.

${ }_{70}$ The surface-intensified warm-core eddies with the signal of the Pacific summer water

${ }_{71}$ are occasionally detected in the vicinity of the Barrow Canyon from later summer to

${ }_{72}$ early autumn [Pickart, 2004]. The detailed properties of a visible warm eddy observed by

${ }_{73}$ the R/V Mirai in 2010 were reported in Nishino et al. [2011a]. The buoyant warm-core

${ }_{74}$ eddy would efficiently supply the surface layer of basin interior with a great amount of

75 ammonium produced by the decomposition of organic matters on the bottom of Chukchi

76 Sea shelf during summer, although the annual nutrient transport of warm eddies might

77 be much smaller than the contribution of cold eddies [Nishino et al., 2005]. The eddy 
WATANABE: WESTERN ARCTIC PRIMARY PRODUCTIVITY REGULATED BY EDDIES $\quad \mathrm{X}-7$

78 transport of ammonium-rich shelf water could sustain locally enhanced growth of smaller-

79 size phytoplankton in the southern Canada Basin. However, it is still unclear whether

so the eddy-like structures of biological signal attributed to the lateral advection of high

${ }_{81}$ phytoplankton biomass from the Chukchi and Beaufort shelf region or were formed by

82 local biological primary production inside the eddies.

In recent years, numerical studies on the Arctic marine biology become activated. The

${ }_{84}$ impact of Arctic sea ice decline on the marine plankton ecosystem was also addressed

${ }_{85}$ using both global simulation products [Popova et al., 2010; Jin et al., 2011] and a pan-

${ }_{86}$ Arctic regional modeling [Zhang et al., 2010]. According to their analyses, the primary

${ }_{87}$ productivity of phytoplankton over seasonal ice areas of the Arctic Ocean is enhanced

${ }_{8}$ primarily by the increases in photosynthetically active radiation and nutrient availability

s9 in the euphotic zone, and partially due to surface water warming. The strong mixing and

s upwelling associated with summertime sea ice reduction are dynamic drivers for nutrient

${ }_{91}$ retrieval. The spatial pattern of ice algae and the size distribution of pelagic phytoplank-

92 ton groups were also reported [Jin et al., 2011]. These models successfully reproduced the

${ }_{93}$ Arctic basin-scale features of CHL and primary production. On the other hand, several

${ }_{94}$ kinds of complexity on the shelf process and shelf-basin exchange for the analysis have

${ }_{95}$ commonly emerged owing to insufficient model resolution to explicitly resolve topographic

96 ocean current, waves, and mesoscale eddies.

${ }_{97} \quad$ Watanabe and Hasumi [2009] and Watanabe [2011] examined 1) mechanisms controlling

${ }_{98}$ the hydrographic properties of the Beaufort shelf-break warm eddies and 2) the relation-

99 ship of Pacific water transport with summertime sea ice extent and shelf-wide wind fields

100 using an eddy-resolving coupled sea ice-ocean model covering the western Arctic Ocean. 


\section{X - 8 WATANABE: WESTERN ARCTIC PRIMARY PRODUCTIVITY REGULATED BY EDDIES}

${ }_{101}$ These previous studies clarified that early sea ice retreat toward the Canada Basin and westerly surface wind over the Chukchi shelf promoted the shelf-to-basin transport of the

${ }_{103}$ Pacific summer water via enhanced eddy activities.

${ }_{104}$ In this paper, the phytoplankton behaviors regulated by the shelf-break warm eddies are addressed using the high-resolution model newly coupled with a lower-trophic marine ecosystem formulation. We performed the model integration from March to November namics, such as shelf-water transportation, turbulent mixing, and upwelling, to primary

${ }_{109}$ productivity following eddy life cycle in the Beaufort shelf-break region. The method of modeling analyses is described in section 2. The seasonal transitions in physical oceano-

111 graphic fields and biological performance in the western Arctic Ocean are traced in section

${ }_{112} 3$, and the eddy-related phytoplankton activities are then focused on in section 4 . The ${ }_{113}$ findings obtained in the present work are summarized in section 5 . 


\section{Model and Experimental Design}




\section{X - 10 WATANABE: WESTERN ARCTIC PRIMARY PRODUCTIVITY REGULATED BY EDDIES}

${ }_{136}$ Zhang et al. [2010]. Their modification of model structure from Kishi et al. [2007] (i.e., ZS 
WATANABE: WESTERN ARCTIC PRIMARY PRODUCTIVITY REGULATED BY EDDIES X - 11 
X - 12 WATANABE: WESTERN ARCTIC PRIMARY PRODUCTIVITY REGULATED BY EDDIES

${ }_{182}$ tion in the western Arctic region, we pick up the 2003 July composite for the shelf field

${ }_{183}$ in section 3.1 and two examples of 2003 and 2010 weekly composites for the eddy field

${ }_{184}$ in section 4.1 . In this paper, we assume $1 \mathrm{mmolN} \sim 80 \mathrm{mgC} \sim 1.6 \mathrm{mgChl}$ based on the

185 mass ratio $\mathrm{C} / \mathrm{CHL}$ of 50 and the Redfield ratio $\mathrm{C} / \mathrm{N}$ of 6.625 for comparison between the

186 model output and the observational estimate with different units, as in Aita et al. [2007]. 
WATANABE: WESTERN ARCTIC PRIMARY PRODUCTIVITY REGULATED BY EDDIES X - 13

\section{Phytoplankton Activity in the Western Arctic Ocean}

\subsection{Model Performance on Phytoplankton Bloom Before Eddy Generation}




\section{X - 14 WATANABE: WESTERN ARCTIC PRIMARY PRODUCTIVITY REGULATED BY EDDIES}

${ }_{208}$ phytoplankton biomass diminished via northward advection [Hill et al., 2005; Watanabe, 209 2011] and local biological process (i.e., mortality, grazing of zooplankton etc.). On the ${ }_{210}$ other hand, the warm and nutrient-rich Pacific water inflowing from the Bering Strait ${ }_{211}$ continuously sustains the phytoplankton bloom in the southern Chukchi shelf, where the ${ }_{212}$ southward increase in surface CHL concentration was detected by the MODIS July composite in 2003 (Figures 2a-b). The vertically integrated PS and PL biomass reaches 366 ${ }_{214} \mu \mathrm{M} \mathrm{m}\left(\sim 586 \mathrm{mgChl} \mathrm{m}^{-2}\right)$ at the Bering Strait in the 2003 case. In reality, the high nitrate concentration over $10 \mu \mathrm{M}$ and the CHL content up to $734 \mathrm{mgChl} \mathrm{m}^{-2}$ were observed at ${ }_{216}$ the strait during the 2002 - 2004 cruises [Lee et al., 2007].

Another feature in Figure 2a is lower phytoplankton biomass in the central Canada ${ }_{218}$ Basin than that over the Chukchi Plateau, although both the regions are still covered ${ }_{219}$ by sea ice packs. The remarkable deepening of nutricline via Ekman downwelling associ${ }_{220}$ ated with the Beaufort High sea level pressure would account for the restricted primary ${ }_{221}$ production in the central basin [Nishino et al., 2011b; Watanabe, 2012]. The nitrate ${ }_{222}$ concentration over the Northwind Ridge is somewhat lower than the WOA09 July clima${ }_{223}$ tological composite (Figure 3), presumably because the wider sea ice opening than the ${ }_{224}$ multi-decadal average promoted the nitrate uptake associated with primary production ${ }_{225}$ for the recent years. In addition, we should consider that the original data of WOA09 ${ }_{227}$ found that the initial bloom is dominated by PL in the entire domain, and the PS habitat ${ }_{228}$ is limited to the Alaskan coastal region south of the Cape Lisburne at the beginning of ${ }_{229}$ July (see yellow contours in Figure 2a). 
WATANABE: WESTERN ARCTIC PRIMARY PRODUCTIVITY REGULATED BY EDDIES X - 15

\subsection{Seasonal Transition in the Barrow Canyon}




\section{X - 16 WATANABE: WESTERN ARCTIC PRIMARY PRODUCTIVITY REGULATED BY EDDIES}

${ }_{252}$ behaviors via grazing process (Figure 4b). ZL biomass averaged in the Barrow Canyon ${ }_{253}$ increases from June to July, and has a peak of $50 \mu \mathrm{Mm}\left(\sim 4.0 \mathrm{gC} \mathrm{m}^{-2}\right)$ at the beginning ${ }_{254}$ of August, when a significant amounts of PS and PL are both alive. To the contrary, ZS

${ }_{255}$ biomass is quite low throughout the blooming season. ZP biomass slightly increases after ${ }_{256}$ July, but the amount is evidently low relative to ZL. Campbell et al. [2009] estimated that ${ }_{257}$ the total copepod biomass in the upper $100 \mathrm{~m}$ of northern Chukchi shelf region seasonally ${ }_{258}$ changed from $0.6 \mathrm{gC} \mathrm{m}^{-2}$ in May - June to $1.9 \mathrm{gC} \mathrm{m}^{-2}$ in July - August, 2002. Since the ${ }_{259}$ ZL biomass recalculated in the top $100 \mathrm{~m}$ is $45 \mu \mathrm{Mm}\left(\sim 3.6 \mathrm{gC} \mathrm{m}^{-2}\right)$ in the 2003 case, 
WATANABE: WESTERN ARCTIC PRIMARY PRODUCTIVITY REGULATED BY EDDIES $\quad$ X - 17 ${ }_{275} \mathrm{~m}$ depth and 0.01 at $60-100 \mathrm{~m}$ depth. The light extinction rate depends on self-shading

${ }_{285}$ [Watanabe and Hasumi, 2009].

286 


\section{X - 18 WATANABE: WESTERN ARCTIC PRIMARY PRODUCTIVITY REGULATED BY EDDIES}

${ }_{298}$ regeneration via nitrification in late summer (Figures 4e-f). The surface nitrate deple- 
WATANABE: WESTERN ARCTIC PRIMARY PRODUCTIVITY REGULATED BY EDDIES $\quad \mathrm{X}-19$

${ }_{321}$ linked to the primary productivity in the Beaufort shelf-break warm eddies unless nutrient 322 compensation occurs in the downstream region. 
X - 20 WATANABE: WESTERN ARCTIC PRIMARY PRODUCTIVITY REGULATED BY EDDIES

\section{Phytoplankton Behaviors associated with Beaufort Shelf-break Eddies}

\subsection{Eddy-like Structure of Phytoplankton Biomass}

${ }_{323}$ In August, a few anti-cyclones spawned from the Barrow Canyon jet and eastward shelf${ }_{324}$ break current intrude into the basin interior [Watanabe, 2011]. The spatial distribution of ${ }_{325}$ combined PS and PL biomass illustrate the swirling structure north of the Barrow Canyon

${ }_{326}$ (Figure 6a). The phytoplankton biomass is clearly higher in an individual eddy than the ${ }_{327}$ surrounding basin area. We found that two examples of MODIS CHL distribution among 328 all weekly composites from 2003 to 2008 were most visible as introduced in section 2 . ${ }_{329}$ First, the eddy-like feature of high CHL concentration appeared north of the Beaufort ${ }_{330}$ shelf break on September 6 - 13, 2003 (Figure 6b), when the warm eddies were detected 331 by the MODIS 11- $\mu$ m brightness temperature [Watanabe, 2011]. The maximum value of 332 CHL concentration reaches $0.3 \mu \mathrm{M}\left(\sim 0.5 \mathrm{mgChl} \mathrm{m}^{-3}\right)$ at $145^{\circ} \mathrm{W}$ and $71^{\circ} \mathrm{N}$. The other 33 feature of eddy-like CHL distribution was captured northwest of Point Barrow on August ${ }_{334} 21-28,2010$ (Figure 6c). The maximum CHL concentration records $0.9 \mu \mathrm{M}(\sim 1.5$ $335 \mathrm{mgChl} \mathrm{m}{ }^{-3}$ ) at $158^{\circ} \mathrm{W}$ and $74^{\circ} \mathrm{N}$. This location is close to the distinct warm eddy tracked 336 by the R/V Mirai cruise during late summer and early autumn in the same year [Nishino ${ }_{337}$ et al., 2011a]. The maximum value of surface phytoplankton concentration on August 27 ${ }_{338}$ in the 2003 case corresponds to $0.4 \mu \mathrm{M}\left(0.6 \mathrm{mgChl} \mathrm{m}^{-3}\right)$ (Figure 6a), which is in the same з39 order as the MODIS values and the observed CHL concentration up to $0.8 \mathrm{mgChl} \mathrm{m}^{-3}$ in ${ }_{340}$ Nishino et al. [2011a] (Figure 3c in their paper). 
WATANABE: WESTERN ARCTIC PRIMARY PRODUCTIVITY REGULATED BY EDDIES $\quad \mathrm{X}-21$

\subsection{Eddy Generation/Development Stage}


X - 22 WATANABE: WESTERN ARCTIC PRIMARY PRODUCTIVITY REGULATED BY EDDIES

${ }_{363}$ eddy stage and that the exchange of biogeochemical properties with background basin 364 environment is not an essential process. 
WATANABE: WESTERN ARCTIC PRIMARY PRODUCTIVITY REGULATED BY EDDIES $\quad \mathrm{X}-23$

\subsection{Eddy Maturity Stage}

The primary production inside the JED is enhanced when the eddy activities become 366 prominent in September (Figure 7c). It can be also detected that a newly generated eddy 


\section{X - 24 WATANABE: WESTERN ARCTIC PRIMARY PRODUCTIVITY REGULATED BY EDDIES}

${ }_{387} 10^{-2} \mu \mathrm{M} \mathrm{day}^{-1}$ in the subsurface layer is significantly smaller than at the ocean surface

${ }_{388}$ (Figure 9c and Table 1). The vertical contrast of GppPS is simply explained by surface

389 light availability that is eight times higher than that at the $60 \mathrm{~m}$ depth. Therefore, the

390 surface central area of shelf-break warm eddies satisfies enough light, nitrate/ammonium,

391 and high-temperature environments, which are all suitable for PS photosynthetic activity.

${ }_{392}$ A key point here is that the primary production of PL is constrained even at the surface

${ }_{393}$ eddy center in contrast to the seasonal dominance in the basin subsurface layer (Figure 9d).

394 Since the light, nitrogenous nutrient (nitrate and ammonium), and temperature conditions

395 including parameter values for PS and PL are same, the lower GppPL is explained by

396 the limited silicate uptake. In fact, the residual silicate concentration is quite low on

${ }_{397}$ the pathway of shelf-origin water through the Barrow Canyon (Figure 4f) and inside the

${ }_{398}$ eddies (Table 1). The demonstrated water temperature and predominance of smaller-size

399 phytoplankton species are consistent with the in-situ measurements conducted by the

${ }_{400}$ R/V Mirai 2010 cruise [Nishino et al., 2011a].

401 The roles of internal eddy dynamics, such as vertical mixing and local up-

402 welling/downwelling, in nutrient redistribution and the consequent regulation of primary

${ }_{403}$ productivity are analyzed. Figure 9e indicates that the enlarged vertical diffusivity up

${ }_{404}$ to $2.7 \times 10^{-2} \mathrm{~m}^{2} \mathrm{~s}^{-1}$ in the upper $80 \mathrm{~m}$ of JED center drives the exchange with under-

${ }_{405}$ lying nutrient-rich water that is also shelf-origin. The localized high vertical diffusivity

${ }_{406}$ is comparable with the tidal mixing of $O\left(10^{-2} \mathrm{~m}^{2} \mathrm{~s}^{-1}\right)$ reported around the Kuril Strait

${ }_{407}$ in the North Pacific [Kawasaki and Hasumi, 2010]. In the COCO model, the vertical

${ }_{408}$ diffusion coefficient is diagnosed using the turbulence closure scheme of Noh and Kim

${ }_{409}$ [1999] at each time step. The turbulent kinetic energy inside the shelf-break eddies arises 
WATANABE: WESTERN ARCTIC PRIMARY PRODUCTIVITY REGULATED BY EDDIES X - 25 
X - 26 WATANABE: WESTERN ARCTIC PRIMARY PRODUCTIVITY REGULATED BY EDDIES

${ }_{433}$ sonal subsurface maximum in the basin interior (Figures 9c-d). In contrast, the deviation

${ }_{434}$ of GppPS and GppPL in the NVNA case from the 2003 case is small inside the JED

${ }_{435}$ relative to that in the NVND case (Figures $10 \mathrm{c}-\mathrm{d}$, Table 1 ). The result suggests that the

436 nutrient redistribution due to local upwelling/downwelling event has a minor contribution

${ }^{437}$ to the primary productivity of shelf-break eddies. The large negative anomaly of GppPL

${ }^{438}$ at the nutricline depth of basin interior is expected to be explained in part by the lack

${ }_{439}$ of wind-driven upwelling of underlying nitrate-rich water, while such basin processes are

${ }_{440}$ out of the scope in this study. 
WATANABE: WESTERN ARCTIC PRIMARY PRODUCTIVITY REGULATED BY EDDIES $\quad \mathrm{X}-27$

\subsection{Eddy Decay Stage}

There is a few reports on the shoaling of nutricline inside the anti-cyclonic eddies ac-

${ }_{442}$ cording to their decay and the corresponding restart of active primary production in the

${ }_{443}$ North Pacific [Ueno et al., 2010]. On the other hand, the model result in the 2003 case

444 shows weakened primary productivity in the southern Beaufort Sea in October (Figure

${ }_{445} 7 \mathrm{~d}$ ), when the vorticity of shelf-break warm eddies gradually shrinks due to lateral fric-

${ }_{446}$ tion [Watanabe, 2011]. The AMSR-E sea ice monitor indicated that the ice freezing

${ }_{447}$ period in the southern Beaufort Sea started during October and November every year in

${ }_{448}$ the 2000s [http://www.ijis.iarc.uaf.edu/cgi-bin/seaice-monitor.cgi]. The autumn sea ice

spread normally precedes the disappearance of shelf-break warm eddies, and the further

${ }_{450}$ eddy shrinking then occurs due to sea ice drag in addition to lateral friction. In the

${ }_{451} 2003$ case, sea ice freezing prevents light absorption at the ocean surface and ceases the

${ }_{452}$ primary production of pelagic phytoplankton species in the most shelf-break region in

${ }_{453}$ mid-October. An exceptional area appears in the vicinity of JED centered at $153^{\circ} \mathrm{W}$ and

${ }_{454} 73^{\circ} \mathrm{N}$ (see the location in Figure $7 \mathrm{~d}$ ). The local delay of sea ice freezing until November 8

${ }_{455}$ occurs attributing to ocean heat content inside the JED. To confirm whether open water

${ }_{456}$ exposure over the shelf-break warm eddies can prolong the photosynthesis period or not in

${ }_{457}$ the southern Beaufort Sea, the JED properties are compared between the eddy maturity

${ }_{458}$ and decay periods (Figure 11).

${ }_{459}$ The temporal changes are characterized by the remarkable decline of GppPS from

${ }_{460} 6.86 \times 10^{-2} \mu \mathrm{M} \mathrm{day}^{-1}$ on September 19 to $0.18 \times 10^{-2} \mu \mathrm{Mday}^{-1}$ on October 31 at the

${ }_{461}$ surface eddy center. The following values are also taken at the same place. During this

${ }_{462}$ period, nitrate (ammonium) concentration recovers from $0.14(0.08) \mu \mathrm{M}$ to $0.55(0.11) \mu \mathrm{M}$ 


\section{X - 28 WATANABE: WESTERN ARCTIC PRIMARY PRODUCTIVITY REGULATED BY EDDIES}

${ }_{463}$ due to the decomposition of organic matter and dynamic processes (Figure 11c). This

${ }_{464}$ change corresponds to the increase in Nit (Amn) term from $0.15(0.29)$ to $0.39(0.36)$ and

${ }_{465}$ has a positive contribution to GppPS. Similarly, the GppPL decrease from $0.57 \mu \mathrm{M}_{\text {day }}{ }^{-1}$

${ }_{466}$ to $0.02 \mu \mathrm{M} \mathrm{day}^{-1}$ is not explained by the Sil term from 0.05 to 0.07 . The rate of decrease

${ }_{467}$ in the Tmp term from 1.25 to 1.04 , which derives from the cooling of ocean surface from

${ }_{468} 3.27^{\circ} \mathrm{C}$ to $0.61{ }^{\circ} \mathrm{C}$, is just $20 \%$. The temperature profile higher than the freezing point of

${ }_{469}$ about $-1.8^{\circ} \mathrm{C}$ with remaining temperature maximum at $130 \mathrm{~m}$ depth certainly can afford

${ }_{470}$ to maintain open water pool at the top of JED. The LA term of 0.32 associated with

${ }_{471}$ the NCEP solar radiation of $10 \mathrm{~W} \mathrm{~m}^{-2}$ at the ocean surface assures the continuance of

${ }_{472}$ photosynthesis in the available nutrient condition after when sea ice covers the shelf-break

${ }_{473}$ region surrounding the JED on October 20. Actually, the LA term decreases from 0.93 on

${ }_{474}$ September 19 to 0.06 on October 31 in the open water area. Sea ice concentration then

${ }_{475}$ increases from 0 to 1 for November 1 to 9 . The daily downward shortwave flux drops to

${ }_{476}$ zero (i.e., polar night all the day) owing to solar incidence on November 8 at $73^{\circ} \mathrm{N}$. Even

${ }_{477}$ taken account for the decrease in PS (PL) biomass itself of $0.19(0.04) \mu \mathrm{M}$ to $0.06(0.02)$

${ }_{478} \mu \mathrm{M}$, it is indicated that the principal factor for the termination of primary production in

${ }_{479}$ spite of nutrient recovery inside the JED is light limitation due to solar incidence rather

${ }_{480}$ than sea ice freezing, and surface cooling has secondary contribution. 
WATANABE: WESTERN ARCTIC PRIMARY PRODUCTIVITY REGULATED BY EDDIES X - 29

\section{Summary and Discussions}

The response of phytoplankton to the Beaufort shelf-break eddies in the western Arctic

${ }_{482}$ Ocean is examined using the eddy-resolving coupled sea ice-ocean model including a lower

${ }_{483}$ trophic marine ecosystem formulation. In the integration from March to November, the

${ }_{484}$ reasonable performance on seasonal phytoplankton bloom following sea ice retreat in the

${ }_{486}$ boundary, and several warm eddies are produced during late summer and early autumn.

${ }_{487}$ The shelf-break warm eddies initially transports the Chukchi shelf water with high primary

${ }_{488}$ productivity toward the Canada Basin interior. In the eddy-developing period, the anti-

${ }_{491}$ internal dynamics in the eddy-maturity period. In particular, the surface central area

${ }_{492}$ of an anti-cyclonic eddy satisfies adequate light, nutrient, and warm environment for

493 photosynthetic activity partly attributing to turbulent mixing with underlying nutrient-

${ }_{494}$ rich water. The simulated biogeochemical properties with the dominance of small-size

495 phytoplankton inside the warm eddies are consistent with the previous in-situ observation

${ }_{496}$ in the western Arctic Ocean. It is also suggested that the light limitation before sea

${ }_{497}$ ice freezing rather than nutrient depletion shuts down the primary production in the 


\section{X - 30 WATANABE: WESTERN ARCTIC PRIMARY PRODUCTIVITY REGULATED BY EDDIES}


WATANABE: WESTERN ARCTIC PRIMARY PRODUCTIVITY REGULATED BY EDDIES X - 31 ${ }_{526}$ observed summertime average of $0.78 \mathrm{gC} \mathrm{m}^{-2}$ day $^{-1}$ in the Chukchi shelf [Hill and Cota, $\left.{ }_{527} 2005\right]$ and might have just a minor impact on the pan-Arctic biogeochemical cycle.

The ship-based in-situ measurements have captured the highest ammonium concentration just above the shallow Chukchi shelf [Nishino et al., 2011b]. The dissolution from sea ${ }_{530}$ bottom sediments is considered to be a crucial nitrogen source in the shelf region and even ${ }_{531}$ in the basin interior throughout the year, although the reliable sequential data has not ${ }_{532}$ been acquired yet. Besides, the benthos communities are assumed to be representative ${ }_{533}$ consumers of particulate and dissolved organic nitrogen [Grebmeier et al., 2006]. The ${ }_{534}$ benthos species might be an important reservoir of nitrogen and possibly modulate ammonium concentration in the deep layer. The ammonium concentration over the Chukchi ${ }_{536}$ shelf bottom is assumed to have a distinct seasonal cycle. Actually, the ammonium con${ }_{537}$ centration more than $4 \mu \mathrm{M}$ was observed along the northern edge of Chukchi shelf during ${ }_{538}$ the summer cruise, while the winter value is below $2 \mu \mathrm{M}$ [Nishino et al., 2005]. Our experiment hence applies the restoring method of ammonium concentration with a seasonal ${ }_{540}$ cycle as described in section 2. The adopted restoring works on controlling the phase ${ }_{541}$ of seasonal variation in the shelf, because we have checked that the experiment without ${ }_{542}$ restoring could not reproduce the observed signal in Nishino et al. [2005, 2011a]. On the ${ }_{543}$ other hand, silicate supply from the shelf bottom is not incorporated because of few obser- 
X - 32 WATANABE: WESTERN ARCTIC PRIMARY PRODUCTIVITY REGULATED BY EDDIES

${ }_{548}$ Chukchi shelf bottom, which have not been quantitatively estimated yet, would be useful ${ }_{549}$ information for further model development. 
WATANABE: WESTERN ARCTIC PRIMARY PRODUCTIVITY REGULATED BY EDDIES $\quad \mathrm{X}-33$

${ }_{550} \quad$ Acknowledgments

${ }_{551}$ We would like to express our sincere gratitude to Dr. Shigeto Nishino at the Japan ${ }_{552}$ Agency for Marine-Earth Science and Technology (JAMSTEC) for his fruitful comments.

${ }_{553}$ This research is funded by Grants-in-Aid for Scientific Research (S) of Japan Society for ${ }_{554}$ the Promotion of Science (JSPS) JFY2010-2014, No. 22221003, "Catastrophic reduction ${ }_{555}$ of sea ice in the Arctic Ocean: its impact on the marine ecosystems in the polar region". ${ }_{556}$ We also appreciate Dr. Naomi Harada at JAMSTEC for the project management. All ${ }_{557}$ numerical experiments were executed using the resources of JAMSTEC Earth Simulator ${ }_{558}$ version 2. The courteous comments and suggestions of anonymous reviewers markedly ${ }_{559}$ benefited the presented product. 


\section{X - 34 WATANABE: WESTERN ARCTIC PRIMARY PRODUCTIVITY REGULATED BY EDDIES}

Appendix: Photosynthesis Formulation in NEMURO

The NEMURO model configuration assumes that the photosynthesis of PS and PL is a function of nitrate $\mathrm{NO}_{3}$, ammonium $\mathrm{NH}_{4}$, and silicate $\mathrm{Si}(\mathrm{OH})_{4}$ concentration, water temperature $T$, light intensity $I$ [Kishi et al., 2007]. The formulation of gross primary production rate of PS (GppPS) and PL (GppPL) consists of nitrate, ammonium, silicate uptake terms (Nit, Amn, Sil, respectively), temperature-dependent term (Tmp), and light availability term (LA), and the biomass itself $P S$ and $P L$ as follows:

$$
\begin{aligned}
& \operatorname{GppPS}=\mathrm{V}_{\operatorname{maxs}}(\underbrace{\frac{N O_{3}}{N O_{3}+\mathrm{K}_{\mathrm{NO}_{3}}} \exp \left(-\Psi N H_{4}\right)}_{[\mathrm{Nit}]}+\underbrace{\frac{N H_{4}}{N H_{4}+\mathrm{K}_{\mathrm{NH}_{4}}}}_{[\mathrm{Amn}]}) \\
& \underbrace{\exp (\kappa T)}_{[\mathrm{Tmp}]} \underbrace{\frac{I}{\mathrm{I}_{\mathrm{opt}}} \exp \left(1-\frac{I}{\mathrm{I}_{\mathrm{opt}}}\right)}_{[\mathrm{LA}]} \underbrace{P S}_{[\mathrm{PS}]}, \\
& \mathrm{GppPL}=\mathrm{V}_{\operatorname{maxl}} \min (\frac{N O_{3}}{N O_{3}+\mathrm{K}_{\mathrm{NO}_{3}}} \exp \left(-\Psi N H_{4}\right)+\frac{N H_{4}}{N H_{4}+\mathrm{K}_{\mathrm{NH}_{4}}}, \underbrace{\frac{S i(O H)_{4}}{S i(O H)_{4}+\mathrm{K}_{\mathrm{Si}(\mathrm{OH})_{4}}} / \mathrm{RSiN}}_{[\mathrm{Sil}]}) \\
& \exp (\kappa T) \frac{I}{\mathrm{I}_{\mathrm{opt}}} \exp \left(1-\frac{I}{\mathrm{I}_{\mathrm{opt}}}\right) \underbrace{P L}_{[\mathrm{PL}]},
\end{aligned}
$$

where the parameter values of maximum phytosynthetic rate at $0^{\circ} \mathrm{C} \mathrm{V}_{\text {maxs }}\left(0.7\right.$ day $\left.^{-1}\right)$, $\mathrm{V}_{\text {maxl }}\left(2.0\right.$ day $\left.^{-1}\right)$, half saturation constant for nitrate $\mathrm{K}_{\mathrm{NO}_{3}}(0.7 \mu \mathrm{M})$, ammonium $\mathrm{K}_{\mathrm{NH}_{4}}$ $(0.2 \mu \mathrm{M})$, silicate $\mathrm{K}_{\mathrm{Si}(\mathrm{OH})_{4}}(1.15 \mu \mathrm{M})$, ammonium inhibition coefficient $\Psi\left(1 \mu \mathrm{M}^{-1}\right)$, temperature coefficient for photosynthetic rate $\kappa\left(0.0693{ }^{\circ} \mathrm{C}^{-1}\right)$, optimum light intensity constant $\mathrm{I}_{\mathrm{opt}}\left(104.7 \mathrm{~W} \mathrm{~m}^{-2}\right)$, and $\mathrm{Si}: \mathrm{N}$ ratio $\mathrm{RSiN}$ of 2 are all given based on Zhang et al. [2010]. The nutrient uptake, Tmp, and LA terms are represented by traditional MichaelisMenten, $\mathrm{Q}_{10}$ relationship, and P-E curve formulation, respectively. 
WATANABE: WESTERN ARCTIC PRIMARY PRODUCTIVITY REGULATED BY EDDIES X - 35

\section{References}

Aita, M. N., Y. Yamanaka, and M. J. Kishi, Effects of ontogenetic vertical migration of zooplankton on annual primary production using NEMURO embedded in a general circulation model, Fish. Oceanogr., 12, 284-290, 2003.

Aita, M. N., Y. Yamanaka, and M. J. Kishi, Interdecadal variation of the lower trophic ecosystem in the northern Pacific between 1948 and 2002, in a 3-D implementation of the NEMURO model, Ecological Modelling, 202, 81-94, 2007.

Arrigo, K. R., G. van Dijken, and S. Pabi, Impact of a shrinking Arctic ice cover on marine primary production, Geophys. Res. Lett., 35, L19,603, doi:10.1029/2008GL035,028, 2008.

Campbell, R. G., E. B. Sherr, C. J. Ashjian, S. Plourde, B. F. Sherr, V. Hill, and D. A. Stockwell, Mesozooplankton prey preference and grazing impact in the western Arctic Ocean, Deep Sea Res., Part II, 56, 1274-1289, 2009.

Garcia, H. E., R. A. Locarnini, T. P. Boyer, J. I. Antonov, M. M. Zweng, O. K. Baranova, and D. R. Johnson, World Ocean Atlas 2009, NOAA Atlas NESDIS, 4, 398pp, 2010.

Grebmeier, J. M., and H. R. Harvey, The Western Arctic Shelf-Basin Interactions (SBI) project: An overview, Deep Sea Res., Part II, 52, 3109-3115, 2005.

Grebmeier, J. M., L. W. Cooper, H. M. Feder, and B. I. Sirenko, Ecosystem dynamics of the Pacific-influenced Northern Bering and Chukchi Seas in the Amerasian Arctic, Progress in Oceanography, 71, 331-361, 2006.

Grebmeier, J. M., H. R. Harvey, and D. A. Stockwell, The Western Arctic Shelf-Basin Interactions (SBI) project, volume II: An overview, Deep Sea Res., Part II, 56, 11371143, 2009. 
X - 36 WATANABE: WESTERN ARCTIC PRIMARY PRODUCTIVITY REGULATED BY EDDIES

Grebmeier, J. M., S. E. Moore, J. E. Overland, K. E. Frey, and R. Gradinger, Biological response to recent Pacific Arctic sea ice retreats, Eos Trans. AGU, 91, 161-163, 2010.

Hasumi, H., CCSR Ocean Component Model (COCO) version 4.0, Rep., Cent. for Clim. Syst. Res., Tokyo, 2006.

Hill, V., and G. Cota, Spatial patterns of primary production on the shelf, slope and basin of the Western Arctic in 2002, Deep Sea Res., Part II, 52, 3344-3354, 2005.

Hill, V., G. Cota, and D. Stockwell, Spring and summer phytoplankton communities in the Chukchi and Eastern Beaufort Seas, Deep Sea Res., Part II, 52, 3369-3385, 2005.

Jin, M., C. Deal, S. H. Lee, S. Elliott, E. Hunke, M. Maltrud, and N. Jeffery, Investigation of Arctic sea ice and ocean primary production for the period 1992-2007 using a 3-D global ice-ocean ecosystem model, Deep Sea Res., Part II, 58, in press, 2011.

Kadko, D., R. S. Pickart, and J. Mathis, Age characteristics of a shelf-break eddy in the western Arctic and implications for shelf-basin exchange, J. Geophys. Res., 113, C02,018, doi:10.1029/2007JC004,429, 2008.

Kalnay, E., M. Kanamitsu, R. Kistler, W. Collins, D. Deaven, L. Gandin, M. Iredell, S. Saha, G. White, J. Woolen, Y. Zhu, M. Chelliah, W. Ebisuzaki, W. Higgins, J. Janowiak, K. C. Mo, C. Ropelewski, J. Wang, A. Leetmaa, R. Reynolds, R. Jenne, and D. Joseph, The NCEP/NCAR 40-year reanalysis project, Bull. Amer. Meteor. Soc., 77, 437-471, 1996.

Kawasaki, T., and H. Hasumi, Role of localized mixing around the Kuril Straits in the Pacific thermohaline circulation, J. Geophys. Res., 115, C11,002, doi:10.1029/2010JC006,130, 2010. 
WATANABE: WESTERN ARCTIC PRIMARY PRODUCTIVITY REGULATED BY EDDIES $\quad$ X - 37

Kishi, J. M., M. Kashiwai, D. M. Ware, B. A. Megrey, D. L. Eslinger, F. E. Werner, M. Noguchi-Aita, T. Azumaya, M. Fujii, S. Hashimoto, D. Huang, H. Iizumi, Y. Ishida, S. Kang, G. A. Kantakov, H. Kim, K. Komatsu, V. V. Navrotsky, S. L. Smith, K. Tadokoro, A. Tsuda, O. Yamamura, Y. Yamanaka, K. Yokouchi, N. Yoshie, J. Zhang, Y. I. Zuenko, and V. I. Zvalinsky, NEMURO - a lower trophic level model for the North Pacific marine ecosystem, Ecological Modelling, 202, 12-25, 2007.

Kishi, M. J., S. Itoh, B. A. Megrey, K. A. Rose, and F. E. Werner, A review of the NEMURO and NEMURO.FISH models and their application to marine ecosystem investigations, J. Oceanogr., 67, 3-16, 2011.

Lee, S. H., T. E. Whitledge, and S.-H. Kang, Recent carbon and nitrogen uptake rates of phytoplankton in Bering Strait and the Chukchi Sea, Continental Shelf Res., 27, 2231-2249, 2007.

Manley, T. O., and K. Hunkins, Mesoscale eddies of the Arctic Ocean, J. Geophys. Res., 90, 4911-4930, 1985.

Mathis, J. T., R. S. Pickart, D. A. Hansell, D. Kadko, and N. R. Bates, Eddy transport of organic carbon and nutrients from the Chukchi Shelf: Impact on the upper halocline of the western Arctic Ocean, J. Geophys. Res., 112, C05,011, doi:10.1029/2006JC003,899, 2007.

National Ice Center, National Ice Center Arctic sea ice charts and climatologies in gridded format, Digital Media, National Snow and Ice Data Center, Boulder, Colorado, 2006.

Nishino, S., K. Shimada, and M. Itoh, Use of ammonium and other nitrogen tracers to investigate the spreading of shelf waters in the western Arctic halocline, J. Geophys. Res., 110, C10,005, doi:10.1029/2003JC002,118, 2005. 
X - 38 WATANABE: WESTERN ARCTIC PRIMARY PRODUCTIVITY REGULATED BY EDDIES

${ }_{641}$ Nishino, S., M. Itoh, Y. Kawaguchi, T. Kikuchi, and M. Aoyama, Impact of an unusually

large warm-core eddy on distributions of nutrients and phytoplankton in the southwestern Canada Basin during late summer/early fall 2010, Geophys. Res. Lett., 38, L16,602, doi:10.1029/2011GL047,885, 2011a.

Nishino, S., T. Kikuchi, M. Yamamoto-Kawai, Y. Kawaguchi, T. Hirawake, and M. Itoh, Enhancement/reduction of biological pump depends on ocean circulation in the sea-ice reduction regions of the Arctic Ocean, J. Oceanogr., 67, 305-314, 2011b.

Noh, Y., and H. J. Kim, Simulations of temperature and turbulence structure of the oceanic boundary layer with the improved near-surface process, J. Geophys. Res., 104, 15,621-15,634, 1999 .

Okkonen, S. R., T. J. Weingartner, S. L. Danielson, D. L. Musgrave, and G. M. Schmidt, Satellite and hydrographic observations of eddy-induced shelf-slope exchange in the northwestern Gulf of Alaska, J. Geophys. Res., 108, C23,033, doi:10.1029/2002JC001,342, 2003.

Pabi, S., G. L. van Dijken, and K. R. Arrigo, Primary production in the Arctic Ocean, 1998-2006, J. Geophys. Res., 113, C08,005, doi:10.1029/2007JC004,578, 2008.

Palmer, M. A., K. R. Arrigo, C. J. Mundy, J. K. Ehn, M. Gosselin, D. G. Barber, J. Martin, E. Alou, S. Roy, and J.-E. Tremblay, Spatial and temporal variation of photosynthetic parameters in natural phytoplankton assemblages in the Beaufort Sea, Canadian Arctic, Polar Biol., 34, 1915-1928, 2011.

Pickart, R. S., Shelfbreak circulation in the Alaskan Beaufort Sea: Mean structure and variability, J. Geophys. Res., 109, C04,024. doi:10.1029/2003JC001,912, 2004. 
WATANABE: WESTERN ARCTIC PRIMARY PRODUCTIVITY REGULATED BY EDDIES X - 39

Popova, E. E., A. Yool, A. C. Coward, Y. K. Aksenov, S. G. Alderson, B. A. de Cuevas, and T. R. Anderson, Control of primary production in the Arctic by nutrients and light: insights from a high resolution ocean general circulation model, Biogeosciences, 7, 3569-3591, 2010.

Spall, M. A., R. S. Pickart, P. S. Fratantoni, and A. J. Plueddemann, Western Arctic shelfbreak eddies: Formation and transport, J. Phys. Oceanogr., 38, 1644-1668, 2008.

Steele, M., R. Morley, and W. Ermold, PHC: A global ocean hydrography with a highquality Arctic Ocean, J. Climate, 14, 2079-2087, 2001.

Sukhanova, I. N., M. V. Flint, L. A. Pautova, D. A. Stockwell, J. M. Grebmeier, and V. M. Sergeeva, Phytoplankton of the western Arctic in the spring and summer of 2002: Structure and seasonal changes, Deep Sea Res., Part II, 56, 1223-1236, 2009.

Sumata, H., T. Hashioka, T. Suzuki, N. Yoshie, T. Okunishi, M. N. Aita, T. T. Sakamoto, A. Ishida, N. Okada, and Y. Yamanaka, Effect of eddy transport on the nutrient supply into the euphotic zone simulated in an eddy-permitting ocean ecosystem model, J. Mar. Sys., 83, 67-87, 2010.

Ueno, H., W. R. Crawford, and H. Onishi, Impact of Alaskan Stream eddies on chlorophyll distribution in the North Pacific, J. Oceanogr., 66, 319-328, 2010.

Walsh, J. J., D. A. Dieterle, F. R. Chen, J. M. Lenes, W. Maslowski, J. J. Cassano, T. E. Whitledge, D. Stockwell, M. Flint, I. N. Sukhanova, and J. Christensen, Trophic cascades and future harmful algal blooms within ice-free Arctic Seas north of Bering Strait: A simulation analysis, Prog. Oceanogr., 91, 312-343, 2011.

Wang, J., G. F. Cota, and J. C. Comiso, Phytoplankton in the Beaufort and Chukchi Seas: Distribution, dynamics, and environmental forcing, Deep Sea Res., Part II, 52, 
X - 40 WATANABE: WESTERN ARCTIC PRIMARY PRODUCTIVITY REGULATED BY EDDIES

${ }_{686} \quad 3355-3368,2005$.

${ }_{687}$ Watanabe, E., Beaufort shelf break eddies and shelf-basin exchange of Pacific summer wa-

${ }_{688}$ ter in the western Arctic Ocean detected by satellite and modeling analyses, J. Geophys. Res., 116, C08,034, doi:10.1029/2010JC006,259, 2011.

Watanabe, E., Linkages among halocline variability, shelf-basin interaction, and wind regimes in the Beaufort Sea demonstrated in pan-Arctic Ocean modeling framework, submitted to Ocean Modelling, 2012.

Watanabe, E., and H. Hasumi, Pacific water transport in the western Arctic Ocean simulated by an eddy-resolving coupled sea ice-ocean model, J. Phys. Oceanogr., 39, 2194$2211,2009$.

Weingartner, T., K. Aagaard, R. Woodgate, S. Danielson, Y. Sasaki, and D. Cavalieri, Circulation on the north central Chukchi Sea shelf, Deep Sea Res., Part II, 52, 3150$3174,2005$.

Zhang, J., Y. H. Spitz, M. Steele, C. Ashjian, R. Campbell, L. Berline, and P. Matrai, Modeling the impact of declining sea ice on the Arctic marine planktonic ecosystem, $J$. Geophys. Res., 115, C10,015, doi:10.1029/2009JC005,387, 2010. 
(a)

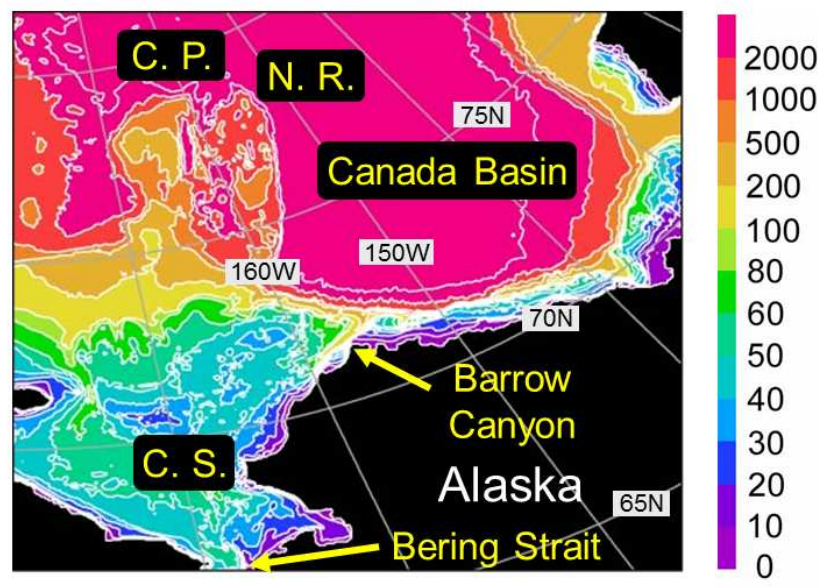

(b)

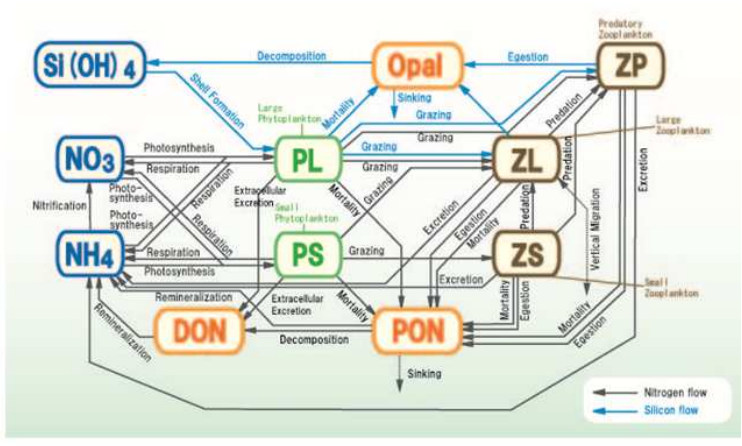

Figure 1. (a) Model bathymetry [m]. The locations include Chukchi Sea (C.S.), Chukchi Plateau (C.P.), and Northwind Ridge (N.R.). (b) NEMURO is composed of small phytoplankton (PS), large phytoplankton (PL), small zooplankton (ZS), large zooplankton (ZL), predatory zooplankton $(\mathrm{ZP})$, nitrate $\left(\mathrm{NO}_{3}\right)$, ammonium $\left(\mathrm{NH}_{4}\right)$, silicate $\left(\mathrm{Si}(\mathrm{OH})_{4}\right)$, opal (Opal), particulate organic nitrogen (PON), and dissolved organic nitrogen (DON). PL and PS are assumed to represent diatom and other non-diatom group (e.g., flagellates, haptophytes), respectively. 
(a)

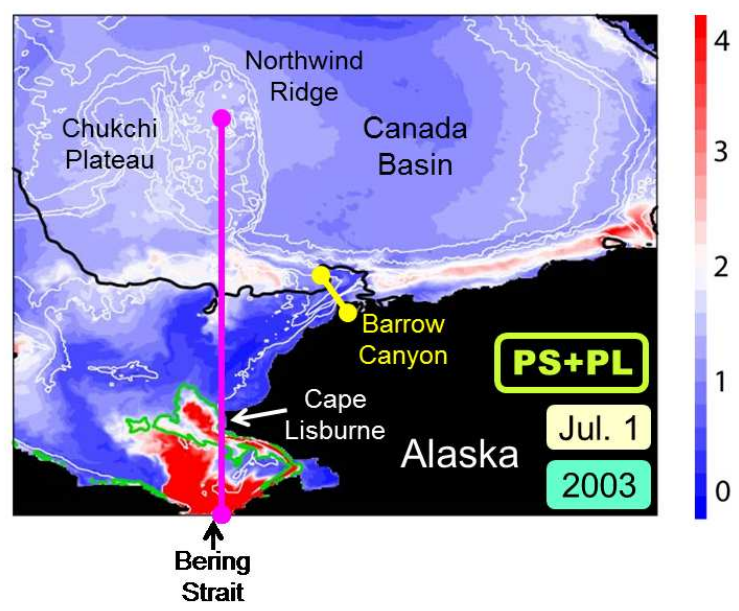

(b)

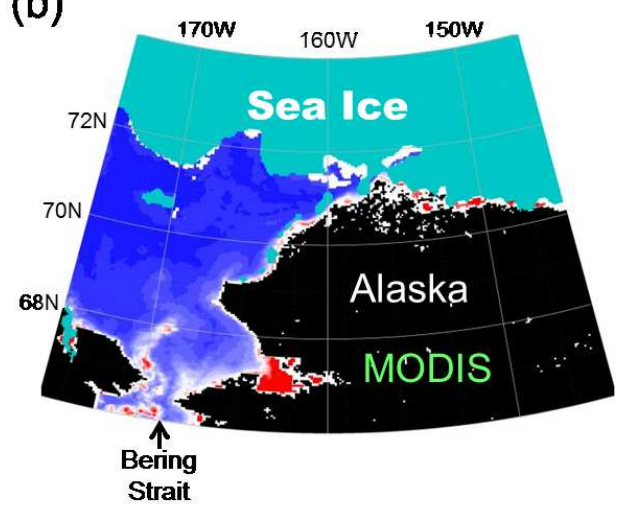

Figure 2. (a) Surface phytoplankton concentration on July 1 in the 2003 case $[\mu \mathrm{M}]$. Sum of PS and PL is shaded, and PS concentration of $0.1 \mu \mathrm{M}$ is plotted by green contours. Black contour shows the simulated sea ice concentration of 0.5 on the same day. White contours show bottom bathymetry. Pink line connected between the Bering Strait and the Northwind Ridge is referred in Figure 3. Yellow line across the Barrow Canyon is referred in Figures 4 and 5. (b) MODIS monthly composite of chlorophyll- $a$ (CHL) concentration in July 2003. Scene ID is A20031822003212. MODIS values with the unit of $\mathrm{mgChl} \mathrm{m}^{-3}$ are divided by 1.6 to directly compare the simulated PS and PL concentration. AMSR-E sea ice area is overlaid by sky-blue shade. 


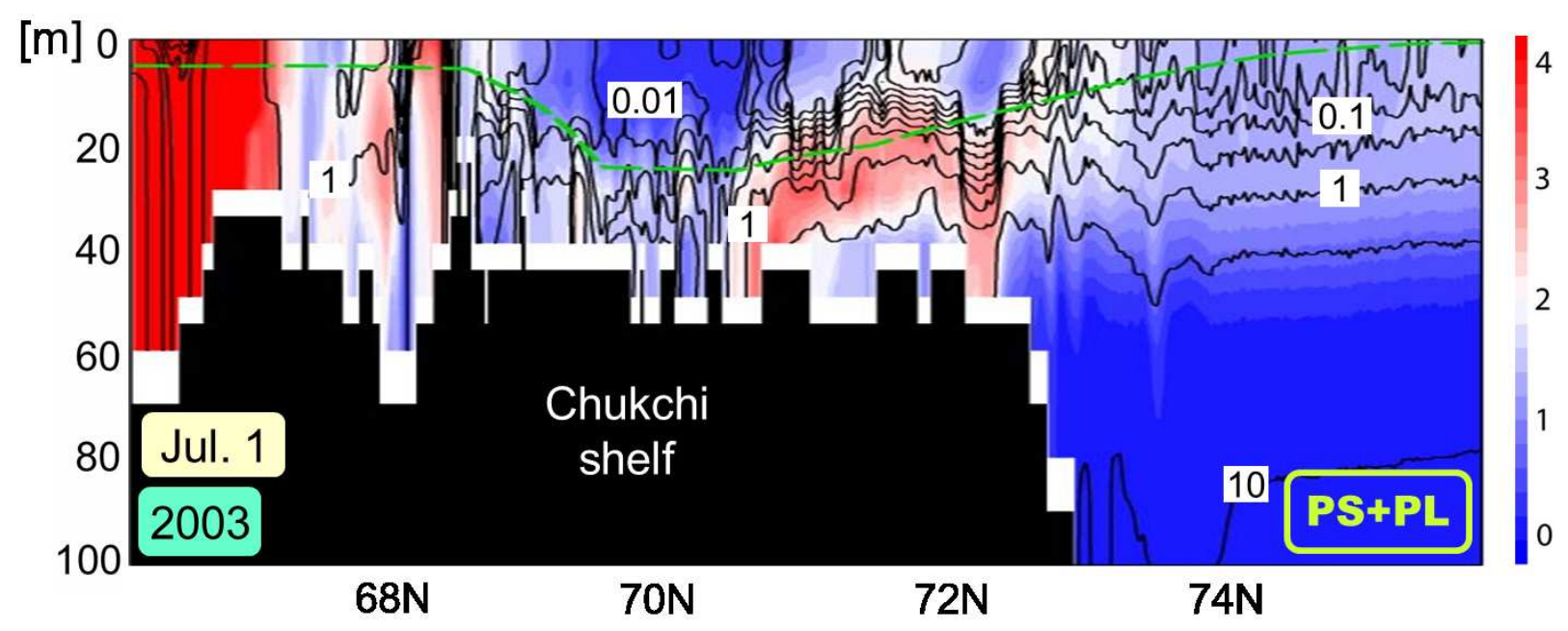

Figure 3. Vertical profile of combined PS and PL concentration along the meridional section from the Bering Strait to the Northwind Ridge (a pink line in Figure 2a) on July 1 in the 2003 case. Black contours show the simulated nitrate concentration with logarithm scale. Unit of both the properties is $\mu \mathrm{M}$. WOA09 July climatology of nitrate concentration of $1 \mu \mathrm{M}$ is overlaid by a green dashed line. 
(a)

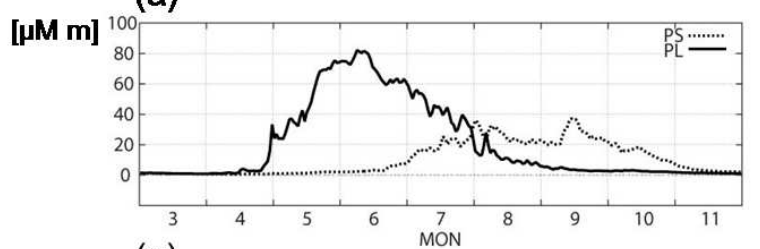

(c)

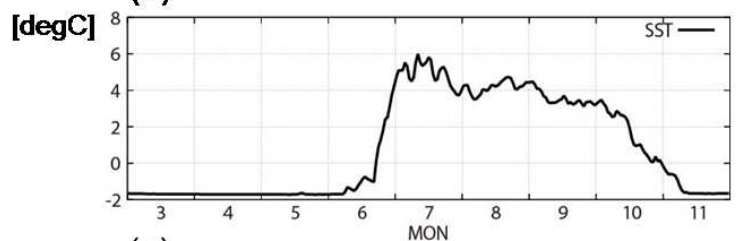

(e)

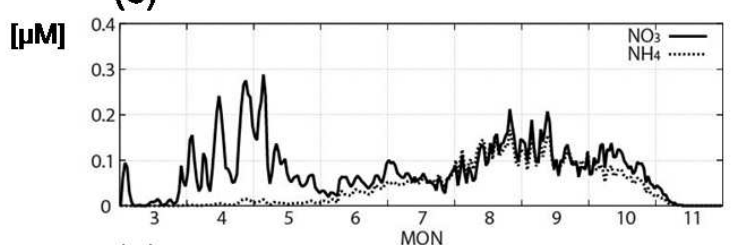

(g)
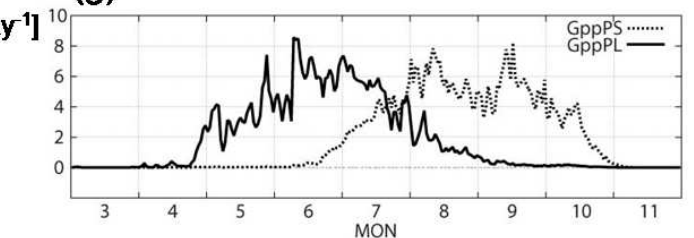

(b)

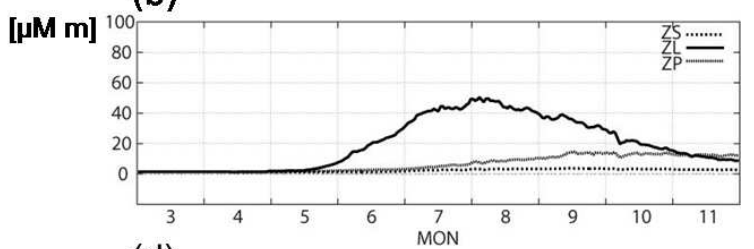

(d)

[-]

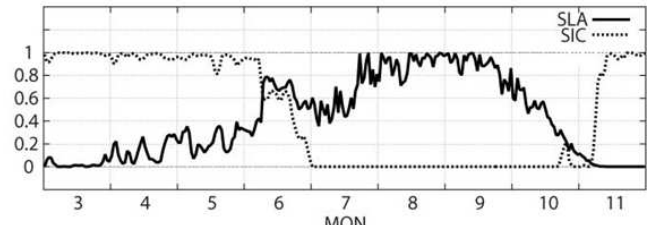

(f)

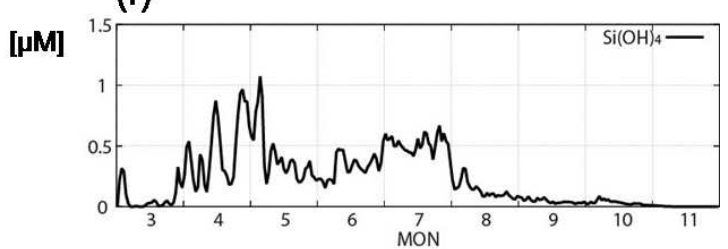

[ $\mu \mathrm{M}$ m day $\left.{ }^{-1}\right]$

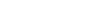

Figure 4. Seasonal variations in simulated biogeochemical and physical properties averaged in the Barrow Canyon section (a yellow line in Figure 2a) in the 2003 case. (a) PS, PL, (b) ZS, ZL, and ZP biomass integrated in the entire water column $[\mu \mathrm{Mm}]$. (c) Sea surface temperature (SST) $\left[{ }^{\circ} \mathrm{C}\right]$. (d) Surface light availability (SLA) and sea ice concentration (SIC) [non-dimension]. (e) $\mathrm{NO}_{3}, \mathrm{NH}_{4}$, and (f) $\mathrm{Si}(\mathrm{OH})_{4}$ concentration weighted by light availability $[\mu \mathrm{M}]$. As for the unit of $\mathrm{Si}(\mathrm{OH})_{4}, 1 \mu \mathrm{M} \equiv 1 \mathrm{mmolSi} \mathrm{m}^{-3}$ is assumed. (g) Gross primary production rate of PS (GppPS) and PL (GppPL) $\left[\mu \mathrm{Mm} \mathrm{day}^{-1}\right]$. See their definition in section 3.2. 


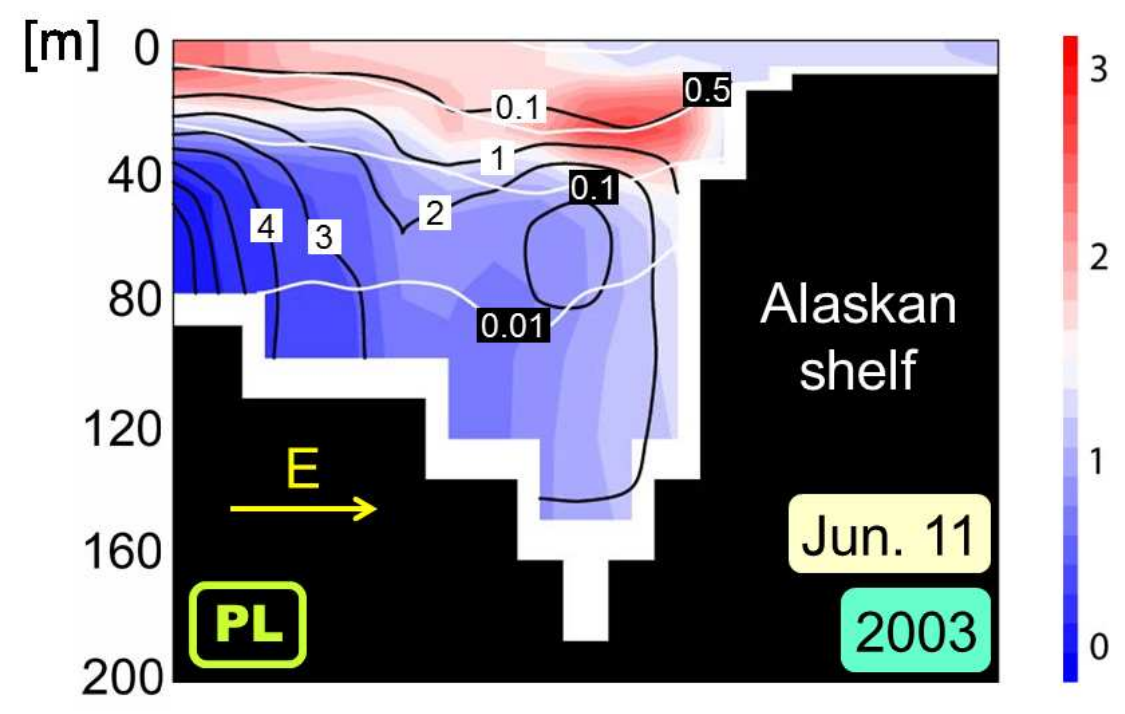

Figure 5. Color shade indicates the vertical profile of PL concentration along the Barrow Canyon section on June 11 in the 2003 case $[\mu \mathrm{M}]$. Black and white contours show the simulated nitrate concentration $[\mu \mathrm{M}]$ and light availability [non-dimension], respectively. 
(a)

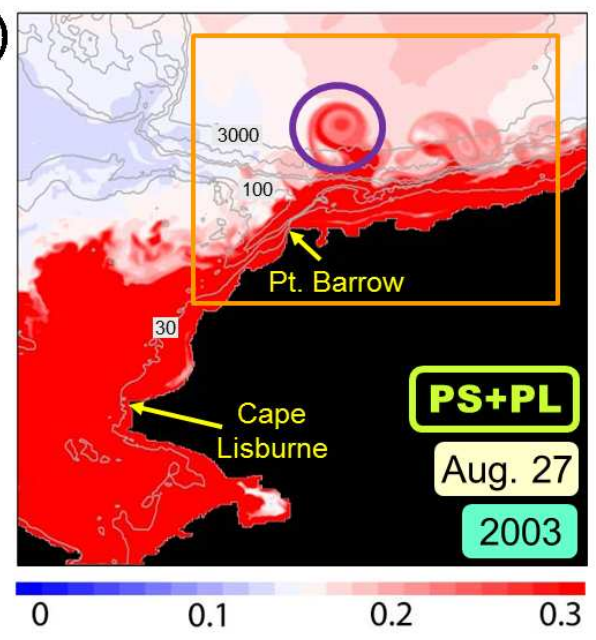

(b)

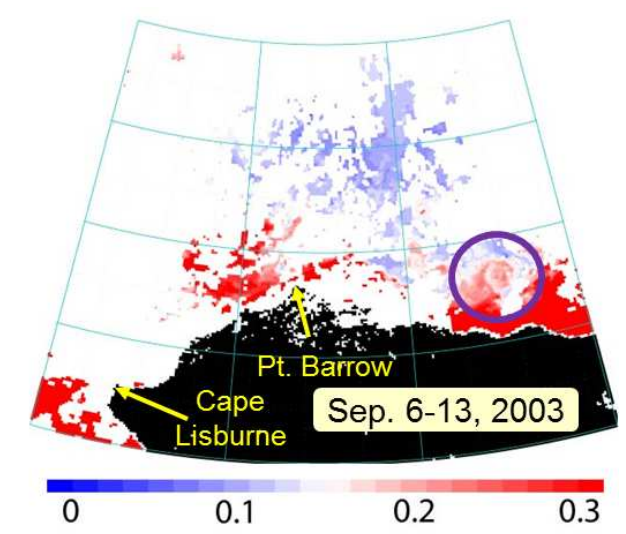

(c)

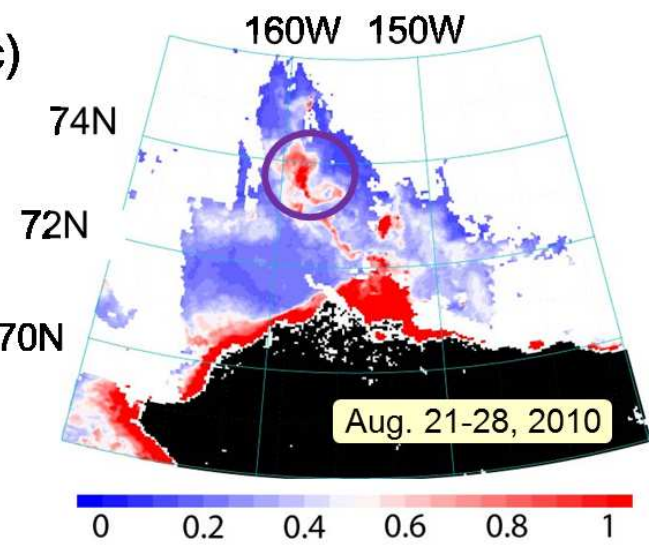

Figure 6. (a) Surface combined PS and PL concentration on August 27 in the 2003 case $[\mu \mathrm{M}]$. Gray contours denote the water depths of $30,60,100,500,1000,2000$, and $3000 \mathrm{~m}$. Orange rectangle is a target region in Figures 7, 8, and 13. MODIS 8-day composites of CHL concentration on (b) September 6 - 13, 2003 and (c) August $21-28$, 2010. Scene ID is (b) A20032492003256 and (c) A20102332010240. MODIS values with the unit of $\mathrm{mgChl} \mathrm{m}^{-3}$ are divided by 1.6 to directly compare the simulated PS and PL concentration. Eddy-like CHL patterns are captured in purple circles. 
(a)

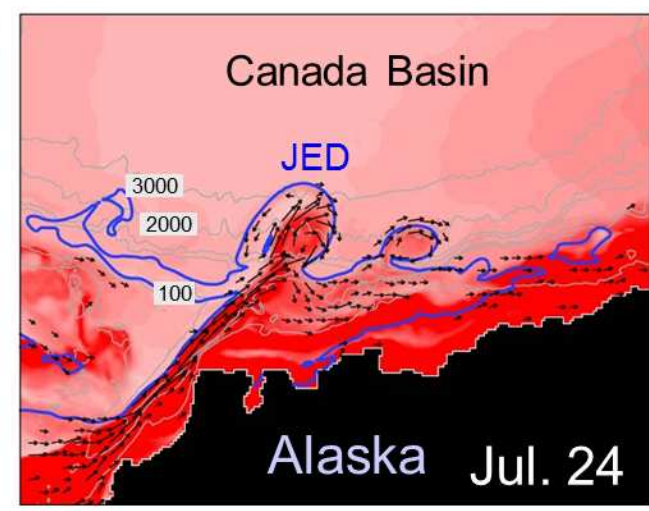

(c)

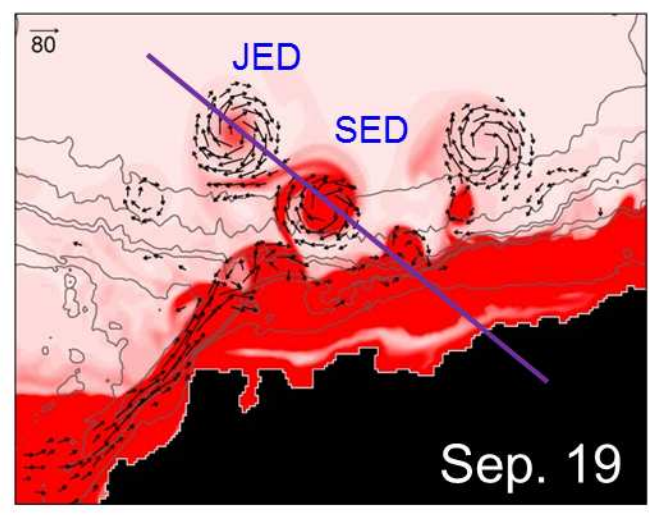

(b)

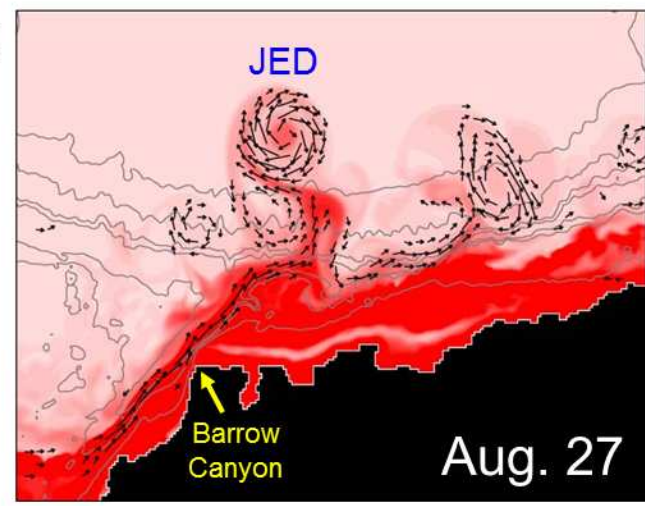

(d)

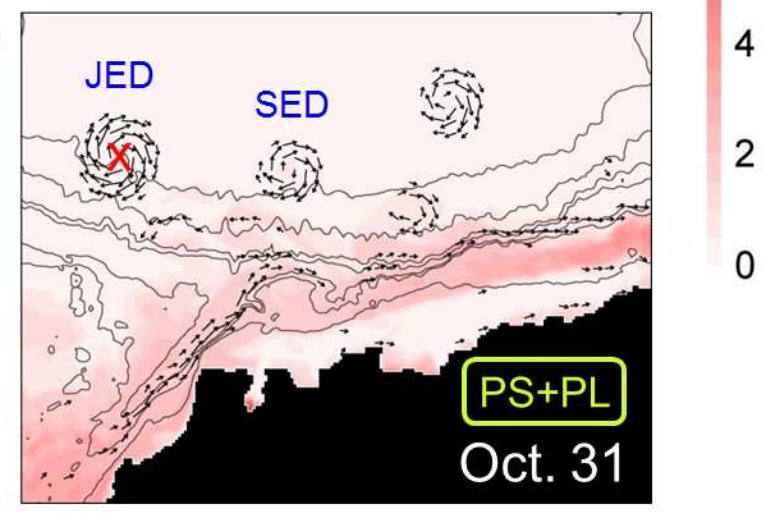

Figure 7. (Shade) Sum of GppPS and GppPL $\left[10^{-2} \mu \mathrm{M}\right.$ day $\left.^{-1}\right]$ and (vectors) horizontal velocity at the ocean surface on (a) July 24, (b) August 27, (c) September 19, and (d) October 31. Unit vector of ocean velocity in (c) is $80 \mathrm{~cm} \mathrm{~s}^{-1}$, and vectors of velocity below $20 \mathrm{~cm} \mathrm{~s}^{-1}$ are hidden. See Figure 6a for each displayed region and gray contours. Surface concentration of Pacific water tracer is 0.1 along blue contours in (a). Purple line across July Eddy (JED) and September Eddy (SED) in (c) is referred in Figures 9 and 10. Red cross in (d) is referred in Figure 11. 

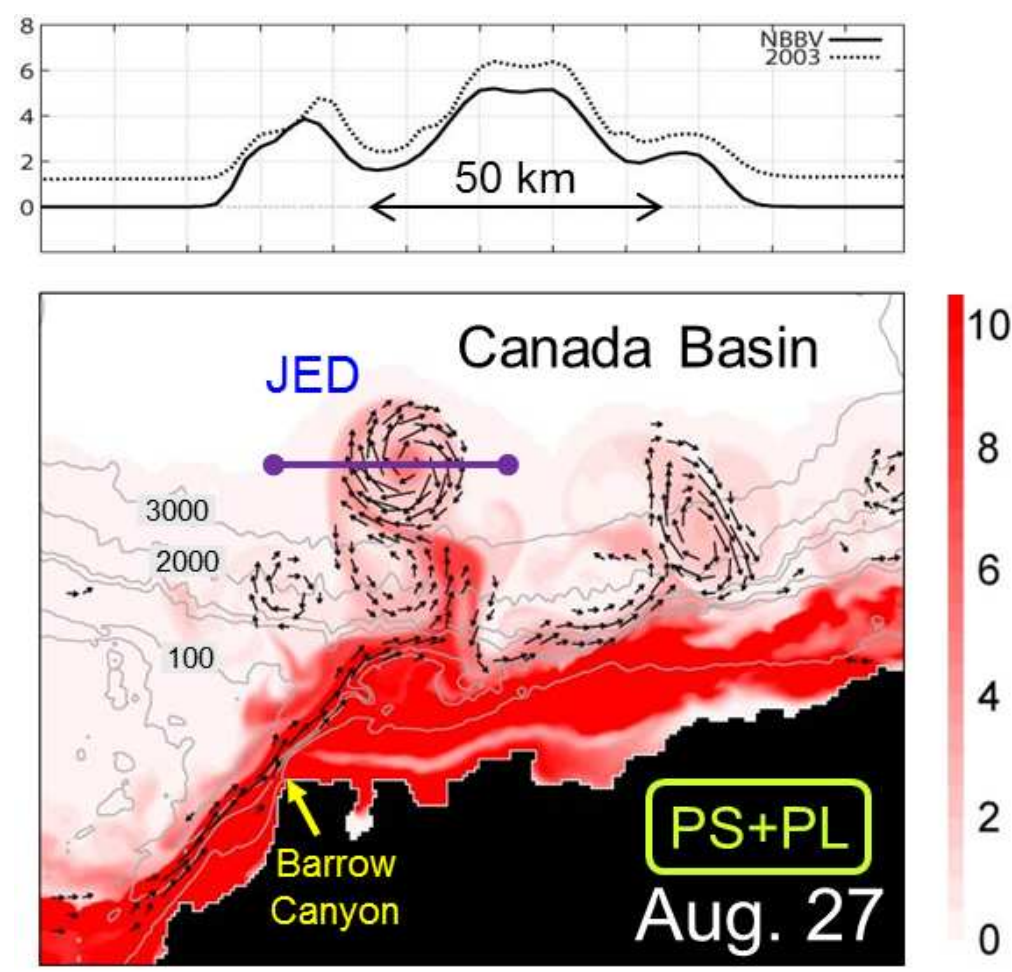

Figure 8. Same as Figure 7b, but in the NBBV case. Top figure shows the sum of surface GppPS and GppPL in the (solid line) 2003 and (dashed line) NBBV cases along a purple line in the bottom figure $\left[10^{-2} \mu \mathrm{M}\right.$ day $\left.^{-1}\right]$. 
(a) [degC]

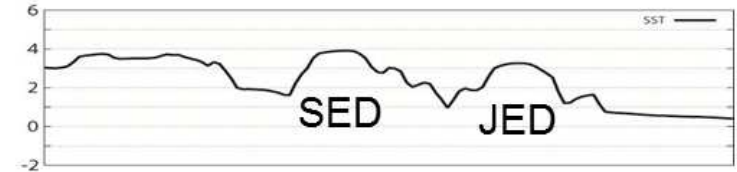

(b)

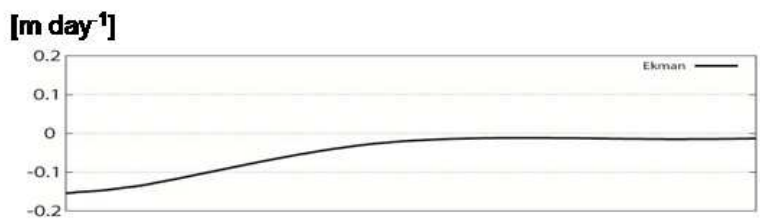

(c)

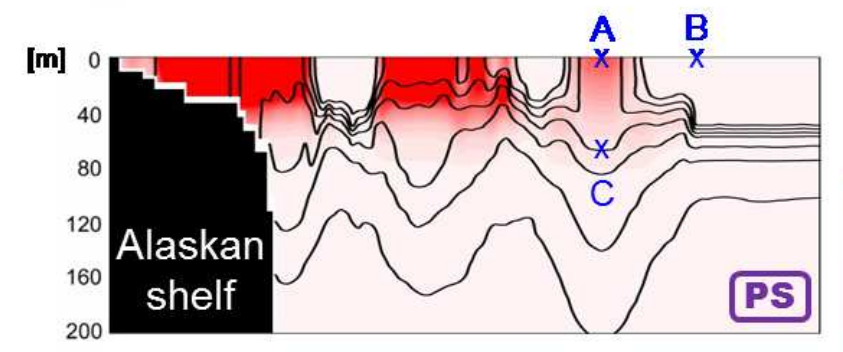

(d)

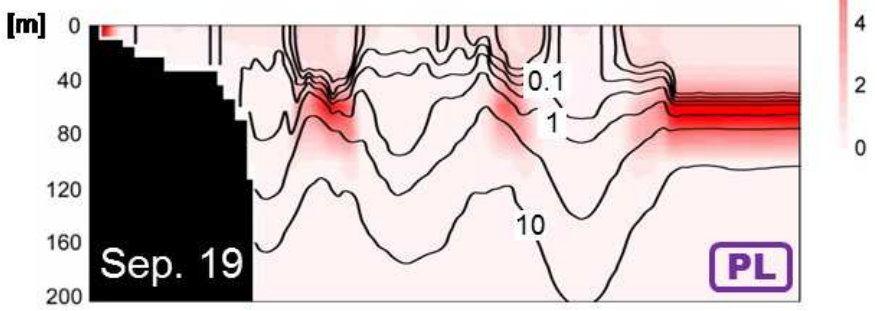

(e)

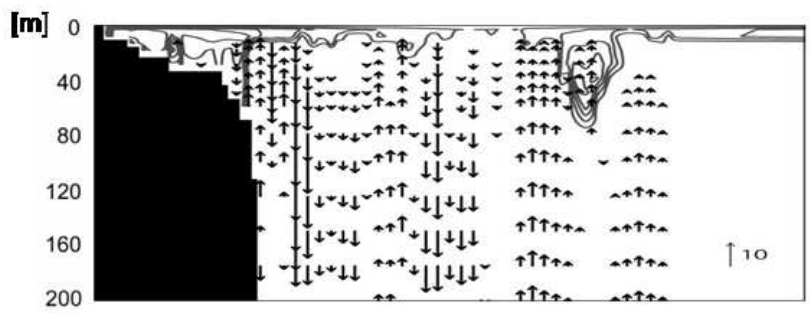

Figure 9. $\quad$ Profiles along a purple line in Figure 7c on September 19 in the 2003 case. (a) SST $\left[{ }^{\circ} \mathrm{C}\right]$ and (b) Ekman upwelling/downwelling calculated from surface wind stress $\left[\mathrm{m} \mathrm{day}^{-1}\right]$. (c) GppPS and (d) GppPL $\left[10^{-2} \mu \mathrm{Mday}^{-1}\right]$. Nitrate concentration is overlaid by contours in (c-d) $[\mu \mathrm{M}]$. (e) (contours) Vertical diffusivity diagnosed by the turbulence mixing scheme and (vectors) vertical velocity. Contour interval is $50 \mathrm{~cm}^{2} \mathrm{~s}^{-1}$. Unit vector of velocity is $10 \mathrm{~m} \mathrm{day}^{-1}$, and vectors of velocity below $1 \mathrm{~m} \mathrm{day}^{-1}$ are hidden. Locations of surface eddy center, surface eddy edge, and subsurface eddy center are labeled as A, B, and C, respectively. 


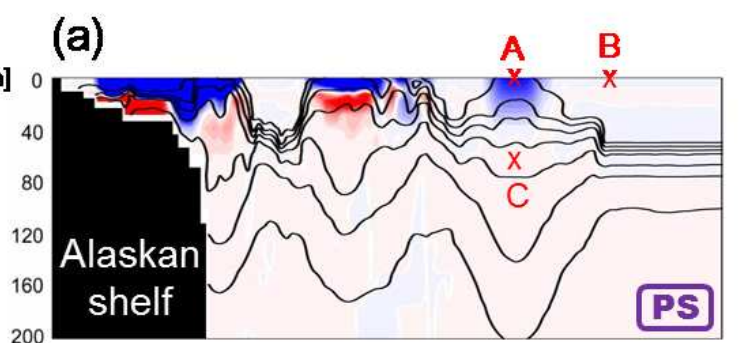

(b)

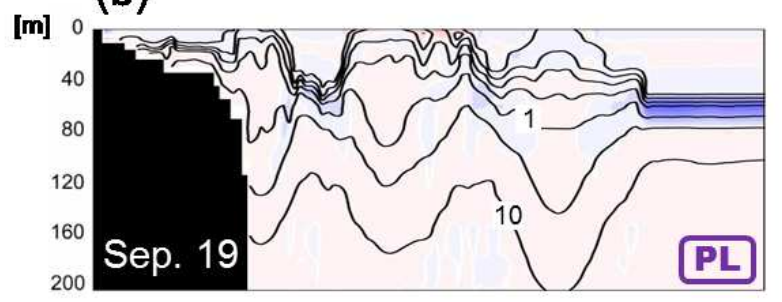

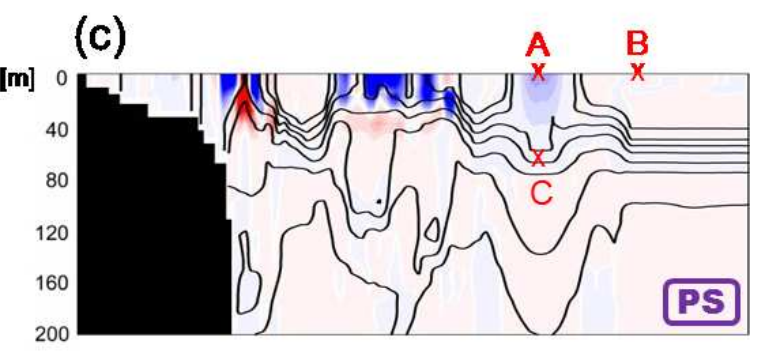

0

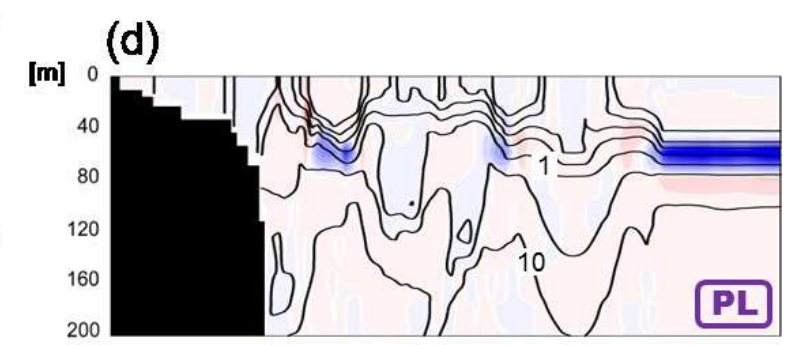

Figure 10. Same as (a,c) Figure $9 c$ and $(b, d)$ Figure $9 d$, but their anomalies in the (a-b) NVND and (c-d) NVNA cases, respectively, from the 2003 case. 

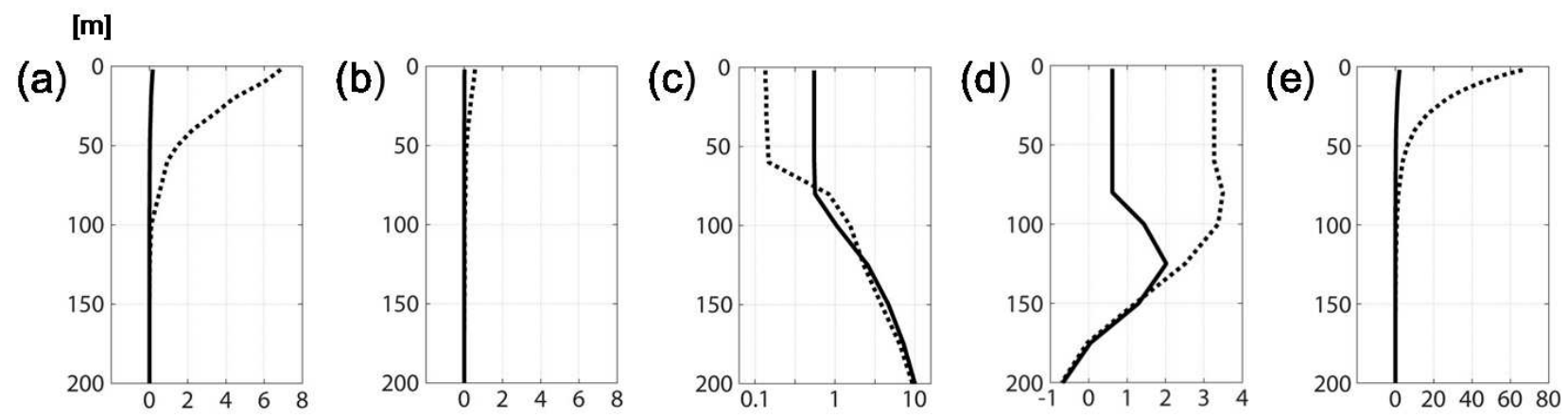

Figure 11. Vertical profiles at the JED center on (dashed line) September 19 and (solid line) October 31 in the 2003 case. See the exact location in Figure 7d. (a) GppPS and (b) GppPL $\left[10^{-2} \mu \mathrm{M}\right.$ day $\left.^{-1}\right]$. (c) Nitrate concentration with logarithm scale $[\mu \mathrm{M}]$, (d) water temperature $\left[{ }^{\circ} \mathrm{C}\right]$, and (e) light intensity $\left[\mathrm{W} \mathrm{m}^{-2}\right]$. 


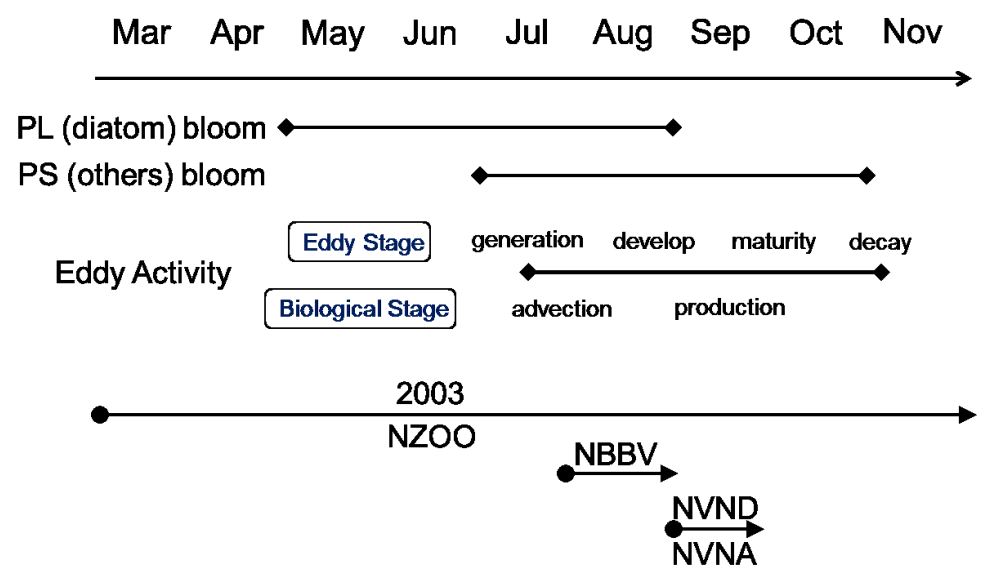

Figure 12. Time lag between phytoplankton bloom in the Chukchi shelf and eddy activity in the Beaufort shelf-break region. Integration periods in each experiment are also attached. 

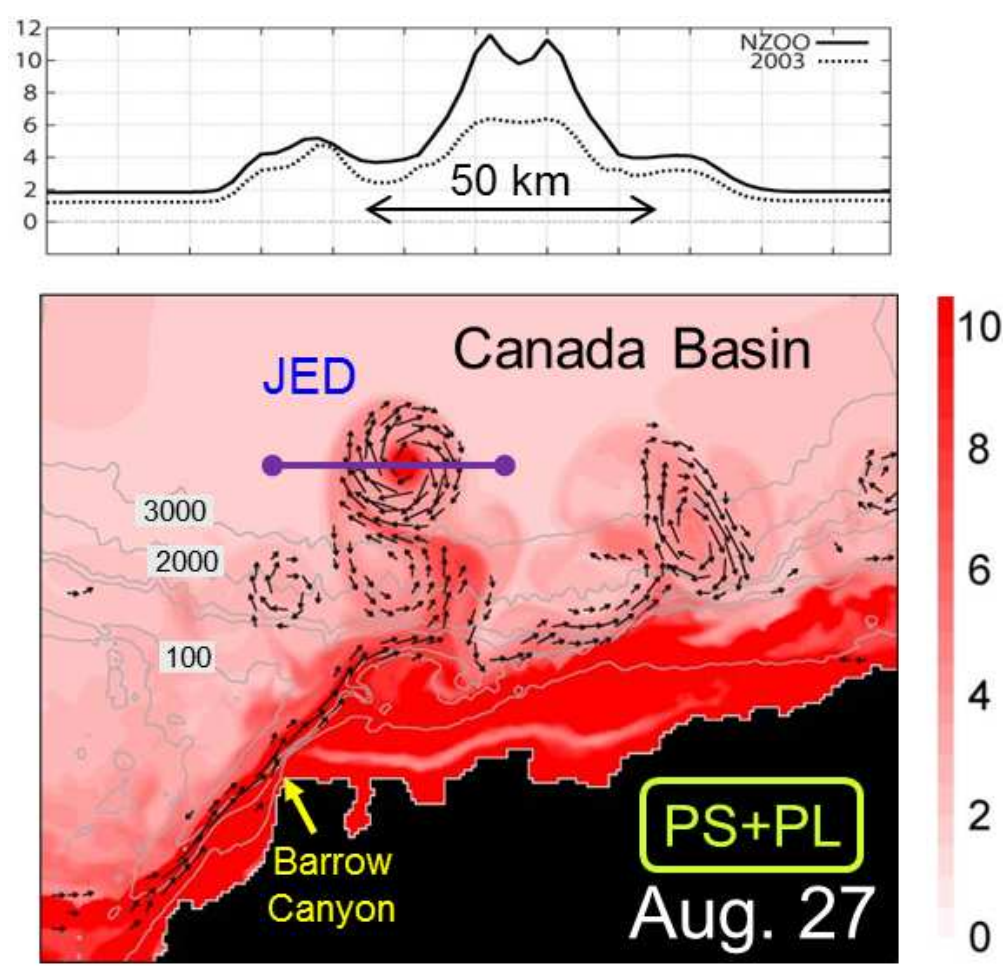

Figure 13. Same as Figure 8, but in the NZOO case. 
Table 1. GppPS, GppPL $\left[10^{-2} \mu \mathrm{M}\right.$ day $\left.^{-1}\right]$, PS, PL $[\mu \mathrm{M}], \mathrm{NO}_{3}, \mathrm{NH}_{4}, \mathrm{Si}(\mathrm{OH})_{4}\left[10^{-2} \mu \mathrm{M}\right], \mathrm{T}$ $\left[{ }^{\circ} \mathrm{C}\right]$, and $\mathrm{I}\left[\mathrm{W} \mathrm{m}^{-2}\right]$ at surface eddy center, surface eddy edge, and subsurface eddy center in Figures 9c-d and 10. Values of each term of photosynthesis formulation (Nit, Amn, Sil, Tmp, LA) are also presented.

\begin{tabular}{|c|c|c|c|c|}
\hline$[2003]$ & & Surface Eddy Center & Surface Eddy Edge & Subsurface Eddy Center \\
\hline GppPS & & 6.86 & 0.01 & 0.93 \\
\hline GppPL & & 0.57 & 0.70 & 0.08 \\
\hline PS & & 0.19 & 0.01 & 0.18 \\
\hline PL & & 0.04 & 0.09 & 0.04 \\
\hline $\mathrm{NO}_{3}$ & (Nit) & $13.55(0.15)$ & $0.20(0.00)$ & $14.76(0.16)$ \\
\hline $\mathrm{NH}_{4}$ & $(\mathrm{Amn})$ & $8.06(0.29)$ & $0.81(0.04)$ & $9.01(0.31)$ \\
\hline $\mathrm{Si}(\mathrm{OH})_{4}$ & $(\mathrm{Sil})$ & $6.59(0.05)$ & $267.89(0.70)$ & $6.92(0.06)$ \\
\hline $\mathrm{T}$ & $(\mathrm{Tmp})$ & $3.27(1.25)$ & $0.70(1.05)$ & $3.27(1.25)$ \\
\hline $\mathrm{I}$ & $(\mathrm{LA})$ & $66.26(0.93)$ & $66.30(0.93)$ & $3.81(0.12)$ \\
\hline$[\mathrm{NVND}]$ & & Surface Eddy Center & Surface Eddy Edge & Subsurface Eddy Center \\
\hline GppPS & & 1.64 & 0.01 & 1.43 \\
\hline GppPL & & 0.21 & 0.61 & 0.18 \\
\hline PS & & 0.13 & 0.01 & 0.13 \\
\hline PL & & 0.04 & 0.09 & 0.04 \\
\hline $\mathrm{NO}_{3}$ & (Nit) & $1.53(0.02)$ & $0.14(0.00)$ & $60.47(0.36)$ \\
\hline $\mathrm{NH}_{4}$ & (Amn) & $3.19(0.14)$ & $0.72(0.03)$ & $24.96(0.56)$ \\
\hline $\mathrm{Si}(\mathrm{OH})_{4}$ & $(\mathrm{Sil})$ & $2.64(0.02)$ & $286.52(0.71)$ & $16.01(0.12)$ \\
\hline $\mathrm{T}$ & (Tmp) & $3.27(1.25)$ & $0.70(1.05)$ & $3.27(1.25)$ \\
\hline $\mathrm{I}$ & $(\mathrm{LA})$ & $66.63(0.93)$ & $66.30(0.93)$ & $4.44(0.14)$ \\
\hline
\end{tabular}

\begin{tabular}{lccc}
\hline [NVNA] & Surface Eddy Center & Surface Eddy Edge & Subsurface Eddy Center \\
\hline GppPS & 5.12 & 0.01 & 0.74 \\
GppPL & 0.44 & 0.71 & 0.06
\end{tabular}

\begin{tabular}{ccccc} 
PS & & 0.17 & 0.01 & 0.16 \\
$\mathrm{PL}$ & & 0.04 & 0.09 & 0.04 \\
& & & \\
$\mathrm{NO}_{3}$ & $(\mathrm{Nit})$ & $8.95(0.11)$ & $0.20(0.00)$ & $9.53(0.11)$ \\
$\mathrm{NH}_{4}$ & $(\mathrm{Amn})$ & $7.41(0.27)$ & $0.82(0.04)$ & $8.24(0.29)$ \\
$\mathrm{Si}(\mathrm{OH})_{4}$ & $(\mathrm{Sil})$ & $5.36(0.04)$ & $260.37(0.69)$ & $5.64(0.05)$ \\
$\mathrm{T}$ & $(\mathrm{Tmp})$ & $3.27(1.25)$ & $0.70(1.05)$ & $3.27(1.25)$ \\
$\mathrm{I}$ & $(\mathrm{LA})$ & $66.41(0.93)$ & $66.30(0.93)$ & $4.05(0.13)$ \\
\hline D R A F T & & June 29, 2012, 10:13am & D R F T
\end{tabular}

